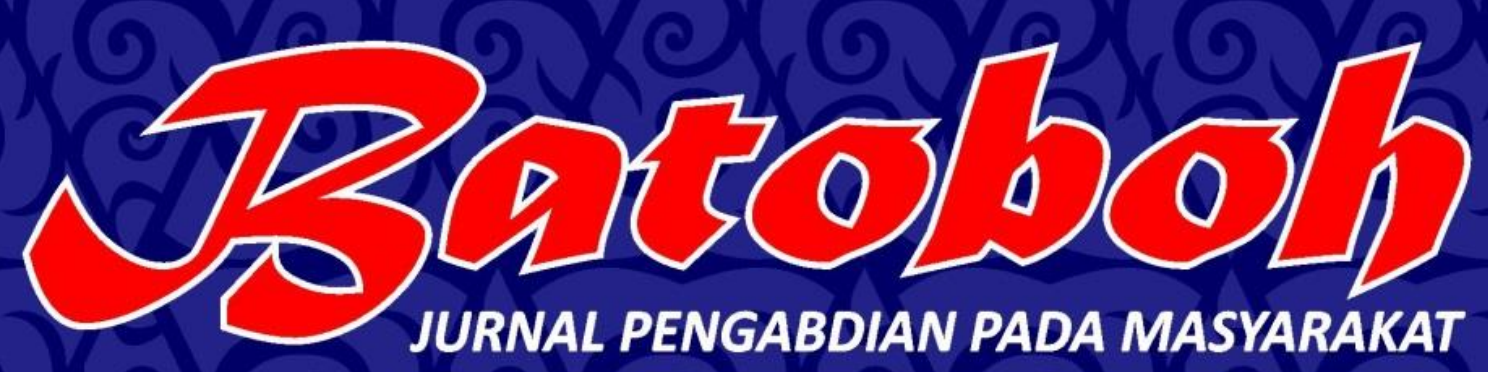

ISSN: 2548-5458

Volume 1

Nomor 2

JURNAL PENGABDIAN PADA MASYARAKAT

Oktober 2016

hlm. 131-266

Yusfil, Zulkifli, Erlinda

PENERAPAN TEKNOLOGI SENI PADA SANGGAR SENI TRADISIONAL

DI KABUPATEN PESISIR SELATAN SUMATERA BARAT

Asril

PELATIHAN LAGU SIONTONG TABANG, KURETA MANDAKI, DAN OYAK TABUIK

PADA GRUP GANDANG TASA ANAK-ANAK, SANGGAR ANAK NAGARI DESA SUNGAI PASAK, KOTA PARIAMAN

Nofrial, Wahyono, Riski Rahmat Kurniawan Dan Alek Hengki Ziora

PEMANFAATAN SERBUK GERGAJI MENJADI PRODUK KERAJINAN DI WAN PERABOT,

TARANTANG KECAMATAN HARAU, 50 KOTA

Dira Herawati, Muhammad Husni, A Nick Koto Agam, Eza Ramadhani

PELATIHAN FOTOGRAFI PADA KEGIATAN EKSTRA KURIKULER DI SMKN 2 PADANGPANJANG

F. X Yatno Karyadi, Eriswan, Bari, Rahmat, Irham

PELATIHAN PEMBUATAN VIDEO DAN FOTO MAKRO MENGGUNAKAN TABLE-TOP STUDIO UNTUK SISWA SMA

Novina Yetri Fatrina, Ediantes, Putri Andam Dewi, Suri Handai Yani

PELATIHAN TEKNIK MEMBUAT RIAS EFEK UNTUK FILM FIKSI PADA SMK 2 PADANGPANJANG

Rosta Minawati, Heri Sasongko, Gilang Febriano, Vini Rusmana

PENGENALAN PRODUKSI FILM DOKUMENTER BAGI SISWA/ SISWI SEKOLAH MENEGAH ATAS

Hafif HR, Fahmi Marh, Ade Sulistiawan, Dino Ashari

PENERAPAN MULTI DISIPLIN SENI DALAM KEGIATAN DRUMBAND PADA EKSTRAKURIKULER SMA 3 PADANGPANJANG

Febri Yulika, Selvi kasman, Putri Khairina Masta

PENINGKATAN KOMPETENSI GURU MELALUI PELATIHAN PENULISAN KARYA TULIS ILMIAH

Darmansyah, Novesar Jamarun, Firdaus, Indra Arifin, Fitra Muhaddis

PELATIHAN INSTRUMEN MUSIK TRADISIONAL MINANGKABAU DI MAN 2 GUNUNG PADANGPANJANG 



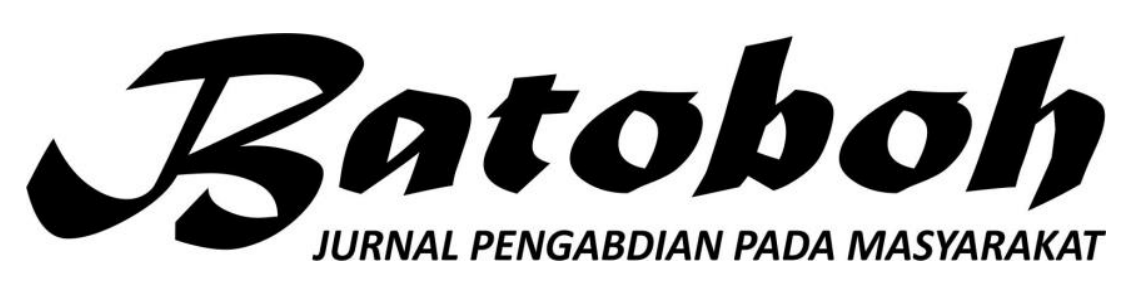

ISSN: 2548-5458 Volume 1, Nomor 2, Oktober 2016, hlm. 131-266

Terbit dua kali setahun pada bulan April dan Oktober. Pengelola Jumal Pengabdian pada Masyarakat merupakan subsistem LPPMPP Institut Seni Indonesia (ISI) Padangpanjang.

\author{
Pengarah \\ Rektor ISIPadangpanjang \\ Penanggung Jawab \\ Kepala Pusat Penerbitan ISI Padangpanjang \\ KetuaPenyunting \\ Andar Indra Sastra \\ Penyunting \\ Asril \\ Sahrul \\ RostaMinawati \\ Harissman \\ Pimpinan Redaksi \\ Saaduddin \\ Redaktur \\ Liza Asriana \\ Rori Dolayance \\ Tata Letak dan Desain Sampul \\ Yoni Sudiani \\ WebJurnal \\ Thegar Risky
}

Alamat Pengelola Jumal Batoboh:LPPMPP ISI Padangpanjang

Jalan Bahder Johan Padangpanjang 27128, Sumatera Barat; Telepon (0752) 82077 Fax. 82803;

e-mail; batoboh@gmail.com

Catatan. Isi/Materi jurnal adalah tanggung jawab Penulis.

Diterbitkan Oleh

Institut Seni Indonesia (ISI) Padangpanjang 


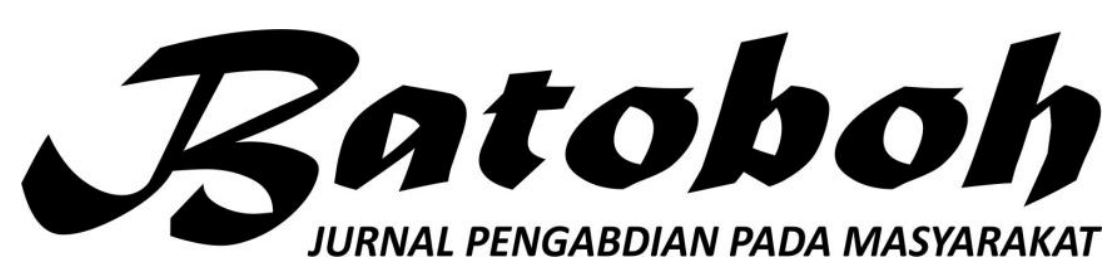

ISSN: 2548-5458 Volume 1, Nomor 2, Oktober 2016, hlm. 131-266

\section{DAFTAR ISI}

\begin{tabular}{|l|l|}
\hline \multicolumn{1}{|c|}{ PENULIS } & \multicolumn{1}{c}{ JUDUL } \\
\hline Yusfil, Zulkifli, Erlinda & $\begin{array}{l}\text { Penerapan Teknologi Seni Pada Sanggar Seni } \\
\text { Tradisional Di Kabupaten Pesisir Selatan Sumatera } \\
\text { Barat }\end{array}$ \\
Asril & $\begin{array}{l}\text { Pelatihan Lagu Siontong Tabang, Kureta Mandaki, } \\
\text { Dan Oyak Tabuik Pada Grup Gandang Tasa Anak- } \\
\text { Anak, Sanggar Anak Nagari Desa Sungai Pasak, } \\
\text { Kota Pariaman }\end{array}$ \\
$\begin{array}{l}\text { Nofrial, Wahyono, Riski } \\
\text { Rahmat Kurniawan Dan } \\
\text { Alek Hengki Ziora }\end{array}$ & $\begin{array}{l}\text { Pemanfaatan Serbuk Gergaji Menjadi Produk } \\
\text { Kerajinan Di Wan Perabot, Tarantang Kecamatan } \\
\text { Harau, 50 Kota }\end{array}$ \\
\hline
\end{tabular}

HALAMAN

Dira Herawati,

Muhammad Husni, A

Nick Koto Agam, Eza

Ramadhani

F. X Yatno Karyadi,

Pelatihan Fotografi Pada Kegiatan Ekstra

Kurikuler Di SMKN 2 Padangpanjang

131-144

$145-164$

Eriswan, Bari, Rahmat, Irham

Novina Yetri Fatrina, Ediantes, Putri Andam Dewi, Suri Handai Yani

Pelatihan Pembuatan Video Dan Foto Makro

190-200 Menggunakan Table-Top Studio Untuk Siswa SMA

Pelatihan Teknik Membuat Rias Efek Untuk Film 201-212 Fiksi Pada SMK 2 Padangpanjang

Rosta Minawati, Heri Sasongko, Gilang

Pengenalan Produksi Film Dokumenter Bagi $213-227$ Febriano, Vini Rusmana

Hafif HR, Fahmi Marh, Ade Sulistiawan, Dino Ashari Siswa/Siswi Sekolah Menegah Atas

$165-181$ 182-189

Febri Yulika, Selvi Kasman, Putri Khairina Masta

Darmansyah, Novesar Jamarun, Firdaus' Indra Arifin, Fitra Muhaddis

Penerapan Multi Disiplin Seni Dalam Kegiatan Drumband Pada Ekstrakurikuler SMA 3 Padangpanjang

Peningkatan Kompetensi Guru Melalui Pelatihan Penulisan Karya Tulis Ilmiah

Pelatihan Instrumen Musik Tradisional $256-266$ Minangkabau Di MAN 2 Gunung Padangpanjang

\footnotetext{
Peraturan Direktur Jenderal Pendidikan Tinggi Kementerian Pendidikan Kebudayaan Republik Indonesia Nomor 1 Tahun 2014 Tanggal Tentang Pedoman Akreditasi Terbitan Berkala Ilmiah. Jumal Batoboh Terbitan Vol. 1, April dan Oktober 2016 Memakaikan Pedoman Akreditasi Berkala Ilmiah Tersebut.
} 


\title{
PELATIHAN LAGU SIONTONG TABANG, KURETA MANDAKI, DAN OYAK TABUIK PADA GRUP GANDANG TASA ANAK-ANAK, SANGGAR ANAK NAGARI DESA SUNGAI PASAK, KOTA PARIAMAN
}

\author{
A s r i l \\ Prodi Seni Karawitan \\ Fakultas Seni Pertunjukan- ISI Padangpanjang. \\ Jl. Bahder Johan, Padangpanjang, Sumatra Barat \\ asrilmuchtar1@gmail.com
}

\begin{abstract}
ABSTRAK
Artikel ini ditulis dari hasil pelatihan gandang tasa lagu Siontang Tabang, Kureta Mandaki, dan Oyak Tabuik yang dilakukan pada grup gandang tasa anak-anak, Sanggar Anak Nagari Desa Sungai Pasak, Kota Pariaman. Grup gandang tasa ini sudah terbentuk sejak pertengahan 2000-an dan telah memiliki lagu sendiri yang disusun oleh pelatih dan pembinanya. Mereka sudah sering melakukan pertunjukan dalam berbagai konteks acara di masyarakat dan mengikuti festival gandang tasa se-kota Pariaman. Untuk meningkatkan kemampuan bermain gandang tasa dan menambah perbendaharaan lagu pada grup anak-anak ini, maka dilakukan pelatihan dengan melatihkan lagu: Siontong Tabang, Kureta Mandaki, dan Oyak Tabuik. Ketiga lagu ini belum mereka mainkan dalam berbagai pertunjukan, sedang ketiga lagu ini sering dimainkan oleh kelompok gandang tasa dewasa di kawasan lain di Kota Pariaman, bahkan di beberapa nagari di Kabupaten Padang Pariaman. Metode pelatihan dilakukan dalam bentuk ceramah (pengarahan), peragaan, dan praktik bersama. Pelatihan materi diberikan secara bertahap, dimulai dari lagu yang lebih mudah hingga ke tingkat yang lebih sulit. Setiap lagu dibagi atas beberapa bagian sebagai materi pelatihan secara menyeluruh, kemudian dibagi sesuai dengan peran memainkan gendang dan tasa, berdasarkan kebiasaan yang berlaku dalam grup.
\end{abstract}

Kata Kunci: pelatihan, gandang tasa, grup gandang tasa anak-anak,Siontong Tabang, Kureta Mandaki, Oyak Tabuik. 


\section{PENDAHULUAN}

Perkembangan gandang tasayang cukup menggembirakan selama satu dekade ini adalah pada kelompok gandang tasa anak-anak dan remaja. Di berbagai desa dan kelurahan di Kota Pariaman dapat dijumpai dengan mudah grup-grup gandang tasa anakanak. Perkembangan ini dapat dilihat dari aspek kuantitas dan kualitas. Perkembangan dari aspek kuantitas ditandai dengan banyaknya muncul grup gandang tasa anak-anak dan remaja. Kehadiran mereka berdampak kuat pada frekuensi pertunjukan yang mereka lakukan dalam berbagai event. Aspek kuantitas, secara umum memunculkan gairah baru pada gandang tasa. Sementara dari aspek kualitas dapat dilihat dari kreasi-kreasi yang muncul dari lagu dan cara mempertunjukkan gandang tasa. Pengolahan ritme-ritme baru, lagu baru, dan cara pertunjukan mereka dengan ekspresi anak-anak yang cenderung riang dan bergairah, menambah semaraknya perkembangan gandang tasa. Perkembangan dari aspek kualitas lebih ditonjolkan pada kreasi-kreasi yang dikembangkan. Gairah perkembangan gandang tasa tidak hanya sebatas dari event pertunjukan yang bersifat adat, tetapi juga diwadahi pada event parade, lomba, dan festival.

Perkembangan ini muncul pada pertengahan 2000-an yang digagas oleh para pembina, pelaku seni tradisi, dan tokoh masyarakat Kota Pariaman. Mereka mengapungkan gagasan agar gandang tasa diajarkan kepada anakanak di usia sekolah, terutama di tingkat Sekolah Dasar. Alasan yang paling logis mengemuka saat itu adalah memberikan apresiasi dan mengajarkan gandang tasa sejak dari awal (usia sekolah), agar gandang tasa bisa menjadi musik tradisi yang hidup bergairah kembali dalam masyarakat Kota Pariaman. Melihat kenyataan pada masa itu, grup gandang tasa yang dimainkan oleh orang-orang dewasa tidak berkembang ke arah yang lebih menggembirakan, bahkan sebagian cenderung 'mati suri'. Grupnya masih ada, tetapi tidak aktif dengan berbagai alasan dan persoalan yang dihadapi, misalnya: gendang tidak cukup, tasa tidak ada, pemain sudah pergi merantau, sudah lupa lagu, dan yang paling dikedepankan menjadi alasan adalah pembina sekaligus guru yang menguasai berbagai lagu sudah tidak di 
kampung. Grup gandang tasa seperti langsung oleh Onten adalah grup ini banyak dijumpai di Pariaman kala gandang tasa Sanggar Anak Nagari di itu, salah satunya di Sungai Pasak. Desa Sungai Pasak. Onten 'meramu' Padahal Sungai Pasak pada era 1960-an sendiri lagu-lagu gandang tasa untuk hingga 1980-an pernah memiliki grup grup anak-anak itu, misalnya gandang tasa yang sangat disegani oleh mengajarkan beberapa lagu yang korong dan nagari lain di sekitarnya. dimiliki oleh grup gandang tasa Meskipun demikian, masih ada kelompok dewasa Sungai Pasak dan beberapa kelompok yang secara lagu-lagu lain yang sudah diolah konsisten mempertahankan grup sekadarnya, sehingga grup anak-anak mereka agar tidak mati, dengan cara itu memiliki pula lagu yang dimainkan tetap melakukan latihan bersama dan sendiri.

selalu melakukan pertunjukan dalam

Perkembangan grup gandang konteks upacara dalam masyarakat, tasa anak-anak Sanggar Anak Nagari seperti pada pesta perkawinan dan lebih Desa Sungai Pasak itu cukup khusus pada pertunjukan ritual Tabuik. membanggakan. Mereka sering tampil Salah seorang penggas yang dalam berbagai pesta perkawinan di sangat berambisi mengajarkan gandang Sungai Pasak sendiri dan di daerah lain tasa kepada anak-anak adalah Onten ${ }^{1}$. hingga pernah menjuarai lomba Dengan berbagai rintangan, upaya gandang tasa tingkat anak-anakse-kota kerasnya membuahkan hasil. Pada Pariaman. Akan tetapi, prestasi ini tidak akhir 2000-an hingga sekarang banyak bisa bertahan lama, setelah munculnya bermunculan grup gandang tasa anak- grup-grup baru gandang tasa anakanak, salah satunya yang dibina anak dari daerah lain di Kota Pariaman dengan lagu-lagu sendiri yang mungkin

${ }^{1}$ Onten adalah pelaku dan pemerhati seni tradisi gandang tasa dan juga seorang pendekar silek. Ibunya berasal dari Koto Marapak, bapaknya dari Sungai Pasak. Ia menetap di Sungai Pasak (di rumah istrinya) dan membina grup gandang tasa anak-anak Desa Sungai Pasak. Onten meninggal dunia sekitar 5 tahun yang lalu pada usia sekitar 55 tahun. lebih menarik dari lagu-lagu yang dimiliki oleh grup gandang tasa anakanak Sanggar Anak Nagari Desa Sungai Pasak.

$$
\text { Menurunnya prestasi yang }
$$
dialami oleh grup gandang tasa anak- 
anak Sanggar Anak Nagari Desa Anak Nagari Desa Desa Sungai Pasak Sungai Pasak memunculkan penting dilakukan.

permasalahan yang bersifat psikis pada Adapun metode yang digunakan mereka, sehingga gairah bermain adalah ceramah, peragaan, dan latihan gandang tasa juga turut menurun. bersama. Ceramah dimaksudkan untuk Anak-anak sebagai generasi yang baru memberikan pemahaman sifat, tumbuh dan masih labil dari segi karakter, ide terciptanya setiap lagu mental dan semangat, sehingga yang diajarkan, agar mereka bisa memerlukan sugesti dan dorongan dari menghayati ekspresi dari setiap lagu. luar untuk membangkitkan kembali gairah dan semangat mereka bermain gandang tasa.Melihat permasalahan ini, salah satu solusi yang perlu diberikan kepada grup gandang tasa anak-anak ini adalah melatihkan lagulagu baru yang belum pernah mereka mainkan sebelumnya, agar mereka mendapatkan tantangan dan motivasi menguasi lagu baru. Lagu-lagu yang dimaksud adalah Siontong Tabang, Kureta Mandaki, dan Oyak Tabuik.

Alasan pemilihan ketiga lagu ini, selain belum pernah mereka mainkan adalah untuk memotivasi semangat dan mentalitas mereka untuk tegak kembali sebagai sebuah grup gandang tasa yang Demonstrasi atau peragaan dimaksudkan agar anak-anak dapat melihat langsung sajian dari setiap lagu yang dilatihkan. Kemudian latihan bersama yang dimaksudkan adalah anak-anak mempraktikkan materi yang diajarkan bersama kelompok mereka. Adakalanya penulis turut pula bermain bersama anak-anak .

Sebelum pelatihan ini dilakukan, penulis menelusuri beberapa catatan, tulisan atau laporan yang terkait dengan materi dan lokasi tempat pelatihan. Ada beberapa tulisan dan laporan pelatihan musik tradisi Minangkabau yang pernah dilakukan oleh orang lain dan penulis sendiri antara lain: Asril (2008) dalam pernah berjaya dengan baik di Kota makalahnya, "Musik Tradisi sebagai Pariaman. Dengan demikian, Penciptaan Karya Baru,” disajikan pada pengabdian melatih gandang tasa pada acara, Pelatihan/Workshop Seni grup gandang tasa anak-anak Sanggar Pertunjukan Indonesia Bagi Sanggar Grup Anak Nagari yang 
diselenggarakan oleh Dinas Parsenibud Kabupaten Tanah Datar di Batu Sangkar 20-21 Oktober 2008. Makalah ini membicarakan beberapa alternatif dalam menyusun musik baru yang bersumber dari musik tradisi, misalnya pendekatan memperluas kosa (bunyi, ditambah dengan instrumen lain sebagai ritme, pencitraan pentas), pendukung. Model musik yang mengeksplorasi sumber-sumber bunyi diciptakan itu, kemudian dilatihkan yang sama sekali baru, kolaborasi, kepada para mahasiswa dan dosen Prodi aransemen, konvensional, dan lain Seni Karawitan ISI Padangpanjang. sebagainya. Dalam makalah ini juga Selain untuk menciptakan model musik dijelaskan pengelolaan produksi lapangan dan arakan, musik ini juga penciptaan musik yang berkaitan akan dijadikan sebagai materi pelatihan dengan materi musik, dan menyarankan untuk musik lapangan.

kepada para pemusik (utusan sanggar) sebaiknya memiliki bekal yang kuat dalam beberapajenis musik tradisi yang akan diolah menjadi musik baru.

Penelitian Mahdi Bahar, dkk., (2010) yang berjudul, "Pemanfaatan Khasanah Tradisi Musik Gandang Tambua Minangkabau dalam Rekayasa Penciptaan Genre Baru Ansambel dan Musik Lapangan (Penciptaan Prototipe Ansambel dan Lagu-lagu Musik Gong Tambur sebagai Model Pengembangan)", membahas konsep musik dan pertunjukan gandang tasa sebagai musik lapangan dan arakan djadikan sebagai pijakan dalam

\section{Profil Grup Gandang Tasa Anak-anak Sanggar Anak Nagari DesaSungai Pasak}

Grup gandang tasa anak-anak Sanggar Anak Nagari Desa Sungai Pasak dibentuk pada pertengahan 2000-an di Dusun Tanjung Bungoran, Sungai Pasak, Kecamatan Pariaman Timur, Kota Pariaman. Berdirinya grup ini sebagai jawaban dari keinginan beberapa tokoh masyarakat dan pembina seni tradisi Kota Pariaman untuk mengajarkan gandang tasa kepada anak-anak. Grup ini dipimpin dan dibina 
langsung oleh Onten, salah dalam desa sendiri untuk tampil, seorang penggagas pengajaran baru mereka latihan dan gandang tasa kepada anak-anak. menampilkan gandang tasa.

Anak-anak yang menjadi anggota grup ini adalah mereka yang masih sekolah di tingkat Sekolah Dasar. Mereka umumnya berasal dari Dusun Tanjung Bungoran, Sungai Pasak. Onten membina grup ini dari dasar dengan berbagai keterbatasan. Yang paling mendasar adalah tidak ada gendang dan tasa yang bisa digunakan sebagai alat musik untuk latihan. Selain itu, anakanak tidak memiliki apresiasi yang memadai dengan gandang tasa, bahkan cenderung belum memiliki. Meskipun di Desa Sungai Pasak sendiri sebenarnya juga terdapat grup gandang tasa kelompok dewasa, tetapi berada di Dusun Sungai Pasak Tengah. Anak-anak dari Dusun Tanjung Bungoran sangat jarang bermain ke Sungai Pasak Tengah untuk menyaksikan latihan dan penampilan gandang tasa. Selain itu, grup gandang tasa kelompok dewasa itu, dapat dikatakan juga tidak begitu aktif, kecuali kalau ada permintaan dari
Onten sebagai seorang pelaku seni tradisi termasuk gandang tasa (sebagai pemain gendang) yang sering bermain dengan grup gandang tasa yang dibina oleh mamaknya sendiri, berupaya keras agar grup anak-anak yang dibinanya bisa latihan. Onten memanfaatkan beberapa galon (kaleng) cat bekas dijadikan sebagai gendang, sedangkan tasa dicari atau dipinjam dari tempat lain. Bagi Onten yang penting, anak-anak bisa mempraktikkan motif-motif ritme gendang pada permukaan galon.

Langkah berikutnya, Onten membuat sendiri gendang berukuran kecil dengan penampang atau resonatornya terbuat dari tripleks. Gendanggendang ini termasuk ringan, sehingga bisa disandang oleh anak-anak seperti orang-orang dewasa memainkan gendang. Dengan tersedianya gendang, maka materi lagu yang diajarkan pun mulai dikuasai oleh anak-anak 
hingga mereka dapat memainkan beberapa lagu dengan baik. Onten mengajarkan lagu-lagu yang dia 'olah' sendiri seperlunya dari lagu-lagu tradisi gandang tasa. Onten juga tidak lupa membagi peran anak-anak tersebut dalam memainkan gendang dan tasa berdasarkan musikalnya.

Penampilan grup gandang tasa anak-anak Sanggar Anak Nagari Desa Sungai Pasak mendapat respons sangat posisitif di kalangan masyarakat. Mereka memainkan lagu-lagu dengan gaya yang sangat ceria, bergaya, bersemangat, dan ekspresif, sesuai pula dengan kondisi emosional mereka yang penuh ceria, sehingga sering mendapat respons aplaus dari penonton. Tampilan grup anak-anak ini dapat dikatakan mampu mangalahkan gaya bermain kelompok gandang tasa dewasa Sungai Pasak. Menariknya penampilan grup anak-anak ini, sehingga mereka laris diundang tampil memeriahkan pesta perkawinan dan mengarak penganten. Mereka tidak hanya tampil di Sungai Pasak, tetapi juga di beberapa daerah lain dalam acara yang sama dan pada konteks acara lainnya. Prestasi yang pernah mereka raih adalah menjadi juara lomba gandang tasa kelompok anak-anak se-kota Pariaman. Selain itu, mereka pernah tampil pada upacara 17 Agustus di Istana Negara Jakarta, dan masih banyak lagi pengalaman mereka tampil di berbagai kota di Sumatra Barat.

Seiring dengan makin berkembangnya grup-grup gandang tasa anak-anak di Kota Pariaman, terutama di desa-desa dan kelurahan yang memiliki basis gandang tasa, maka grup gandang tasa anak-anak Sungai Pasak mendapat saingan berat, hingga mengalahkan mereka dalam festival. Salah satu grup gandang tasa anak-anak yang menjadi saingan beratnya adalah grup gandang tasa anak-anak dari Desa Cubadak Air, Kecamatan Pariaman Utara. Sejak munculnya grup ini di pentas festival gandang tasa anakanak se-kota Pariaman, maka sejak itu pula grup gandang tasa anakanak Sungai Pasak kehilangan 
prestasi puncaknya. Keunggulan grup gandang tasa anak-anak Cubadak Air terletak pada lagulagu yang mereka mainkan. Mereka mampu memainkan lagulagu kelompok orang dewasa yang terbilang sangat sulit, misalnya lagu Alihan Anam, Oyak Ambacang, dan lain sebagainya. Sementara lagu Siontong Tabang dan Kureta Mandaki merupakan lagu yang sudah umum dimainkan pada kelompok ini.

Selain munculnya saingan dari grup-grup lain, grup gandang tasa anak-anak Sungai Pasak kehilangan pelatih dan pembinanya. Onten meninggal dunia pada 2010 yang lalu. Peran Onten yang sangat berpengaruh dan kharismatik bagi anak-anak, bahkan sudah seperti orang tua mereka sendiri, dengan meninggalnya Onten menjadi pukulan kuat bagi mereka, hingga semangat mereka pun turut berkurang. Peran Onten kini digantikan oleh anaknya sebagai pembina dan pelatih.

\section{Gandang Tasa sebagai Pilihan Materi yang Dilatihkan}

Gandang tasa merupakan musik tradisi yang paling banyak digemari oleh masyarakat di Kota Pariaman, tak terkecuali di Desa Sungai Pasak. Apresiasi masyarakat terhadap gandang tasa cukup tinggi. Bahkan Sungai Pasak pada era 1960-an hingga 1980-an pernah memiliki grup gandang tasa (kelompok dewasa) yang sangat solid dan terkenal di sekitar Pariaman. Grup gandang tasa ini sering tampil dalam berbagai upacara dalam masyarakat dan kegiatan yang dilakukan oleh pemerintah. Mereka tidak saja tampil di sekitar kampung-kampung di Kota Pariaman dan Kabupaten Padang Pariaman, tetapi juga sering tampil di Kota Padang.

Dalam rentang waktu tiga dasawarsa lebih sejak 1980-an hingga sekarang, prestasi dan kebesaran nama grup gandang tasa Desa Sungai Pasak sudah tidak ada lagi dan hanya tinggal kenangan. Meskipun saat ini ada kelompok gandang tasa dewasa, tetapi 
mereka tidak memiliki prestasi lainnya. Selain itu, lagu tersebut yang membanggakan. Prestasi juga dimainkan di beberapa nagari gandang tasa Sungai Pasak justeru di Kabupaten Padang Pariaman, dibangkitkan oleh grup anak-anak. terutama yang berdekatan dengan Namun sangat disayangkan pula Pariaman Utara. Berbeda dengan prestasi mereka juga cepat lagu Oyak Tabuik, lagu ini 'tenggelam' karena munculnya termasuk 'populer' di berbagai grup gandang tasa anak-anak yang desa dan kelurahan di Kota lebih bagus dan unggul dari segi Pariaman, bahkan di beberapa lagu-lagu yang mereka miliki. nagari di Kabupaten Padang Untuk membangkitkan Pariaman. Anak-anak Sungai semangat mereka kembali bermain Pasak sudah memiliki apresiasi gandang tasa, maka salah satu dengan lagu ini. Dengan solusinya adalah melatihkan dilatihkannya lagu-lagu di atas, gandang tasa dengan lagu yang diharapkan gairah baru bisa berbeda dan belum mereka muncul lagi bagi grup gandang mainkan. Seperti sudah dijelaskan tasa anak-anak Sanggar Anak Nagari sebelumnya, bahwa lagu yang Desa Sungai Pasak.

dipilih adalah Siontong Tabang, Untuk memahami lebih jauh Kureta Mandaki, dan Oyak Tabuik. konsep dan struktur gandang tasa, Khusus pada lagu Siontong Tabang berikut ini dijelaskan secara dan Kureta Mandaki, lagu ini singkat hal-hal yang terkait dengan merupakan lagu yang tidak mereka gandang tasa, sebagaimana yang kenal dan mainkan sebelumnya. pernah penulis deskripsikan pada Lagu ini 'populer' dan hanya artikel lain yang pernah dimuat di dimainkan oleh kelompok- jurnal Humaniora, vol. 27 No. 1 Feb. kelompok gandang tasa yang 2015.

berada di desa-desa di sekitar Gandang tasa adalah Pariaman Utara, Kota Pariaman, ansambel musik perkusi ritmik seperti Cubadak Air, Sikapak, yang terdiri atas 6-10 buah gendang Pakotan, dan beberapa desa bermuka dua (double-headed drum) 
dan sebuah tasa, jenis gendang berupa satu motif atau pola ritme bermuka satu (single-headed drum). pendek, dan ada pula dua hingga Lagu-lagu yang dimainkan, hanya tiga motif/pola ritme. Setiap motif dibangun dari permainan pola ritme- atau pola ritme itu dimainkan 2-3 pola ritme gendang dengan tasa. kali dengan tasa, selanjutnya diikuti Tidak ada instrumen yang berfungsi oleh semua gendang. Dalam tradisi sebagai pembawa melodi, tidak ada pertunjukan gandang tasa, tidak ada gendang yang ditala/distem dengan suatu kesepakatan secara verbal atas nada-nada tertentu yang difungsikan lagu yang akan dimainkan. Para sebagai melodi, seperti instrumen pemain gendang harus taganing (jenis gendang) pada mendengarkan pola ritme pangka ansambel gondang sabangunan di matam yang dimainkan oleh pemain masyarakat etnik Batak Toba di tasa. Matam adalah bagian pokok Sumatra Utara (Purba, 1991; Pasaribu, atau inti lagu. Bentuk matam ada 1992). Kekuatan musikalnya hanya dua macam, yaitu: pertama, dalam tertumpu pada permainan- bentuk pola ritme pendek yang permainan pola ritme. Karakter dimainkan berulang-ulang; kedua, musiknya bersifat energik, bersuara gabungan dari susunan beberapa keras, dan penyajiannya cenderung pola ritme. Jenis matam yang kedua atraktif, sehingga musik ini sangat mendominasi dan menguasai pada prosesi dan lapangan terbuka. (Asril, 2015: 220).

Struktur lagu gandang tasa menurut Asril, terdiri atas tiga bagian, yaitu: matam, pangka matam, dan ikua matam. Pangka matam adalah bagian awal atau pembuka lagu (semacam intro lagu). Pola ritme pangka matam pada setiap lagu berbeda-beda, ada yang biasanya berwujud dalam bentuk pola ritme yang lebih panjang. Terakhir, ikua matam adalah pola ritme yang digunakan sebagai kode untuk mengakhiri lagu (Asril, 2016: 237).

\section{Aplikasi Pelatihan}

Metode pelatihan yang digunakan terdiri dari: metode ceramah, metode peragaan/ demonstrasi, dan metode latihan 
bersama. Metode ceramah digunakan untuk menjelaskan halhal yang terkait dengan masingmasing lagu. Metode peragaan atau demonstrasi digunakan untuk melihatkan kepada anak-anak peserta pelatihan lagu-lagu yang akan dilatihkan, agar dapat menjadi pedoman dan rujukan bagi mereka. Adapun metode latihan bersama adalah melatihkan materi yang telah disiapkan, mulai dari bagian perbagian hingga penggabungan lagu dan penggabungan gendang dengan tasa.

Lagu Siontong Tabang, Kureta Mandaki, dan Oyak Tabuik memiliki karakter yang berbeda masing-masingnya, disebabkan oleh inspirasi penciptaan dan riwayat penggunaannya dalam ritual atau adat. Dalam pemberian materi pelatihan, karakter, sumber inspirasi penciptaan, dan kegunaan masing-masing lagu tersebut menjadi bagian materi pelatihan yang diberikan kepada anak-anak.

\subsection{Lagu SiontongTabang}

4.1.1. Metode ceramah

Metode ceramah diberikan untuk menjelaskan apa saja yang terkait dengan lagu Siontong Tabang. Lagu SiontongTabang adalah sebuah lagu yang menggambarkan seekor burung yang bernama "siontong" sedang terbang. Burung ini cenderung hinggap dan tinggal di pohon-pohon yang telah mati. Dinamika perjalanan burung itu seperti, meninggi dan merendah, kian lama kian cepat, digambarkan pada lagu ini dalam bentuk permainan dinamik yang kadang-kadang keras, kadang-kadang melemah/melunak. Selain itu, tempo lagu juga kian lama kian cepat, sebagai gambaran bahwa ia (burung) makin mendekati sasarannya.

Pada bagian awal, lagu ini dimainkan dengan suara atau bunyi yang tidak terlalu keras (pukulan tidak maksimal pada gendang), karena pencerminan dan perepresentasian dari karakter burung (siontong) sesungguhnya juga bukan tipe yang keras. Ciri khas dari lagu ini adalah tekanan terkuat pada gendang jatuh pada pukulan atas (up beat), sehingga memberikan kesan ritmik yang berayun. Sementara untuk 
menghidupkan lagu dan kedalaman isinya dilahirkan melalui ritme tasa. Pola ritme gendang pada dasarnya dimainkan dalam bentuk unisono.

Pemilihan lagu Siontong Tabangsebagai lagu pertama, yang diajarkan berdasarkan prinsip dari sederhana ke kompleks. Tasa dan gendang dalam lagu ini pada bagianbagian tertentu memiliki permainan ritme yang sama. Penempatan ritmeritme tasa dalam permainan gendang bisa berpedoman pada ciri-ciri tertentu, sehingga mudah diketahui dalam permainan secara keseluruhan.

\subsubsection{Metode peragaan}

Sebelum lagu Siontong Tabang dilatihkan, penulis meragakan terlebih dulu pola ritme pangka matam lagu dengan tasa dan pola ritme pangka matam yang dimainkan dengan gendang. Peragaan ini dilakukan secara bertahap berdasarkan penggalanpenggalan materi lagu yang telah penulis siapkan. Setelah peragaan, praktik dilanjutkan oleh anak-anak ke alat musik.

\subsubsection{Metode latihan bersama}

Praktik materi yang dilatihkan pertama sekali pada gendang. Semua anak-anak mencobakan secara bersama-sama pola ritme-pola ritme yang diajarkan. Setelah mereka bisa memainkan, penulis mencobakan latihan bersama dengan anak-anak tersebut sambil diiringi dengan tasa. Cara ini dilakukan berulang-ulang hingga mereka merasakan penggabungan gendang dengan tasa. Kemudian dilanjutkan pada materi berikutnya, yaitu matam hingga mengakhiri lagu (ikua matam). Semua anak-anak diharuskan menguasai motif dan pola ritme gendang. Jika mereka sudah mampu memainkan gendang dengan baik hingga merasakan permainan pola ritme dan perubahannya serta struktur lagu, maka baru mereka diberi kesempatan belajar memainkan tasa. Oleh karena, syarat belajar memainkan tasa, pemainharus mampu dan mahir terlebih dulu memainkan gendang. Pemain tasa merupakan komando dalam pertunjukan gandang tasa. Kode dan perubahan termasuk durasi pertunjukan sangat tergantung dari kode-kode musikal berupa motif dan pola ritme yang disampaikan melalui tasa. Pada bagian matam, tasa akan memainkan beberapa motif ritme yang dimainkan bersama gendang. Bagian ini termasuk 
sulit, karena pemain tasa harus menghafal belasan hingga puluhan

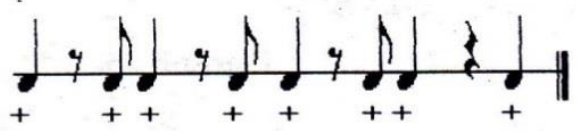

motif ritme tasa, termasuk penempatannya pada pola ritme ostinato gendang.

Adapun materi pelatihan lagu Siontong Tabang dapat dituliskan
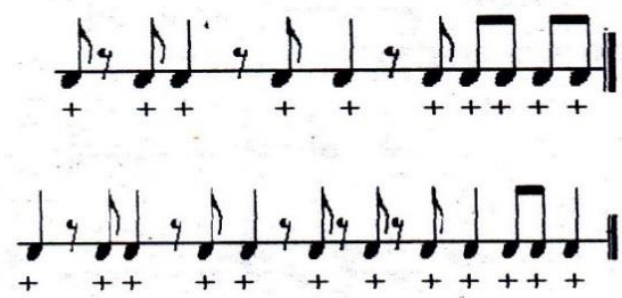
melalui beberapa notasi berikut ini.

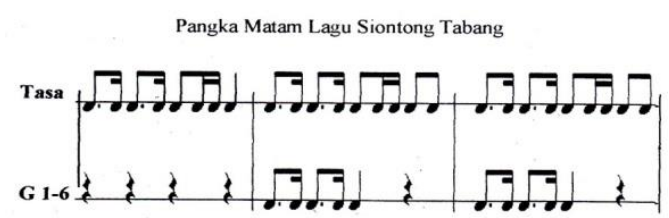

Notasi: pola ritme ikua matam lagu Siontong Tabang

\subsection{Lagu Kureta Mandaki}

\subsubsection{Metode ceramah}
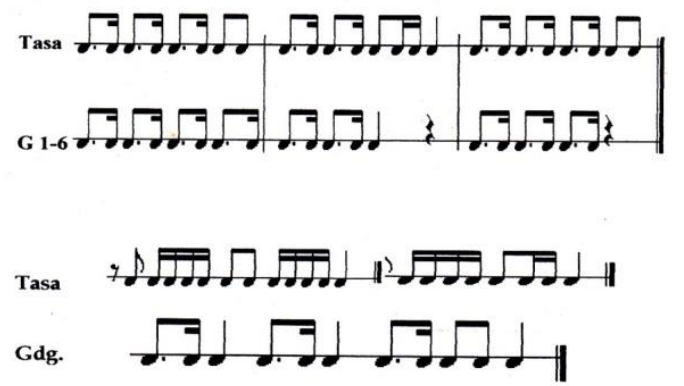

Contoh beberapa motif/pola ritme tasapada matam lagu Siontong Tabang.
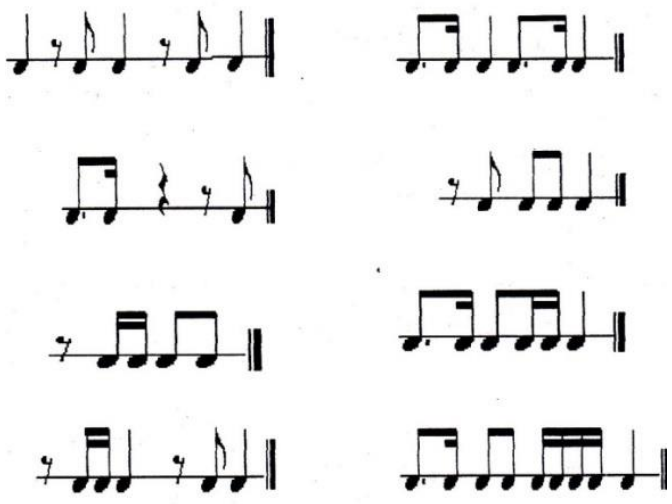

Bagian akhir lagu Siontong Tabang ditutup dengan ikua matam.

Lagu Kureta Mandaki terinspirasi dari pengalaman perjalanan di atas kereta api. Pada masa lalu menjelang tahun 1950-an, orang-orang dari Pariaman yang hendak berpergian ke Padangpanjang, Bukittinggi, Payakumbuh, Solok, Sawahlunto, dan sekitarnya, sering menggunakan jasa kereta api, karena pada masa itu belum ada mobil untuk daerah tujuan di atas. Bunyi roda-roda kereta api pada setiap gerbong di setiap persambungan rel ternyata menghasilkan motif-motif ritmik tingkah meningkah yang sangat menarik. Dari perpaduan bunyi ritmik roda dan rel kereta api itulah yang ditransformasikan oleh senimanseniman gandangtasa ke dalam beberapa buah gendang. Dari beberapa 
buah gendang itu dimainkan beberapa motif ritme yang saling berbeda, hingga menghasilkan jalinan ritme imitasi roda dengan rel.

Untuk menggambarkan keadaan kereta api sedang mendaki biasanya para seniman gandangtasa memainkan bagian tertentu dari lagu KuretaMandaki dengan tempo lambat, tetapi suaranya keras. Artinya, di sini pada saat seperti itu digambarkan keadaan kereta api sedang mengeluarkan tenaga ekstra untuk mendaki. Cara ini secara tidak langsung juga sebagai permainan dinamik pada lagu ini. Lagu Kureta Mandaki dimulai dari tempo sedang berangsur-angsur cepat dan stabil pada tempo cepat beberapa saat sebelum berakhir. Tempo cepat dan stabil ini, seolah-olah menggambarkan suasana sudah berada di jalan yang datar dan mendekati pemberhentian (stasiun).

Dasar menempatkan lagu Kureta Mandakipada bagian kedua dari materi pelatihan adalah pertimbangan pada tingkat kesulitan memainkannya, dibandingkan dengan lagu Siontong Tabang. Tingkat kesulitan pada lagu ini berada pada permainan beberapa ostinato pola ritme-pola ritme gendang yang berbeda antara satu dan yang lainnya, sehingga muncul pula sedikit kesulitan untuk menentukan tandatanda di mana menempatkan ritme tasa. Meskipun demikian, tingkat kesulitannya masih dapat dilakukan oleh pemain pemula, sehingga kategori lagu Kureta Mandaki dapat diletakkan pada tingkat sedikit lebih sulit.

Dilihat dari pola ritme-pola ritme, tasa memang lebih sulit, begitu juga pola ritme-pola ritme gendang yang tidak sama, sehingga jalinan gendang lebih menentukan tingkat kesulitan itu, yaitu menempatkan pola ritme-pola ritme tasa ke atas permainan pola ritme gendang.

\subsubsection{Metode peragaan}

Metode peragaan pada lagu Kureta Mandaki pada dasarnya sama dengan yang diberikan pada lagu Siontong Tabang, yaitu mencontohkan pola ritme tasa dan gendang, sejak dari pangka matam, matam hingga ikua matam. Peragaan ini dilakukan secara bertahap, dan yang lebih khusus adalah motif ritme tasa dan penempatannya pada bagian matam. Berbekal pada pengalaman latihan lagu Siontong Tabang, anak-anak dapat menyesuaikan 
dengan cepat tahap-tahap pelatihan dan penguasaan materi.

\subsubsection{Metode latihan bersama}

Praktik yang lebih penting adalah latihan bersama memainkan gendang dan tasa. Penulis mengambil posisi sebagai pemain tasa, sedangkan anakanak memainkan gendang. Praktik bersama ini dilakukan secara bertahap dan berulang-ulang, hingga anak-anak dapat merasakan bermain gendang dengan baik, merasakan paduan antara gendang dengan tasa, dan merasakan penempatan motif-motif ritme tasa pada gendang. Berikut ini beberapa contoh pola ritme pangka matamdan matamgendang dan tasa.

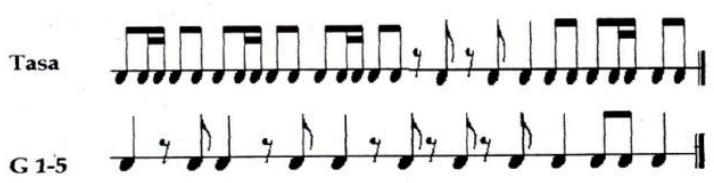

Notasi: pangka matam Kureta Mandaki

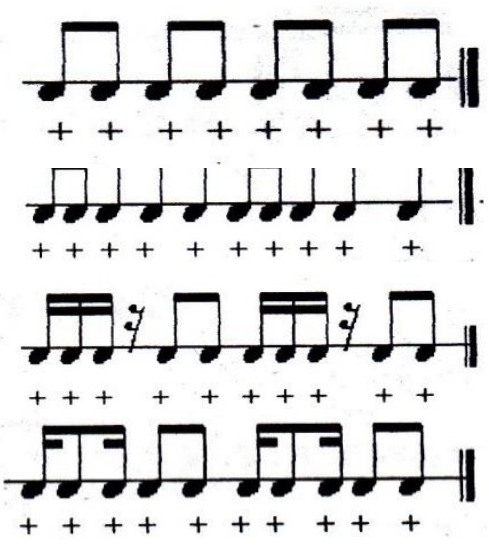

Notasi: pola ritme matam Kureta Mandaki

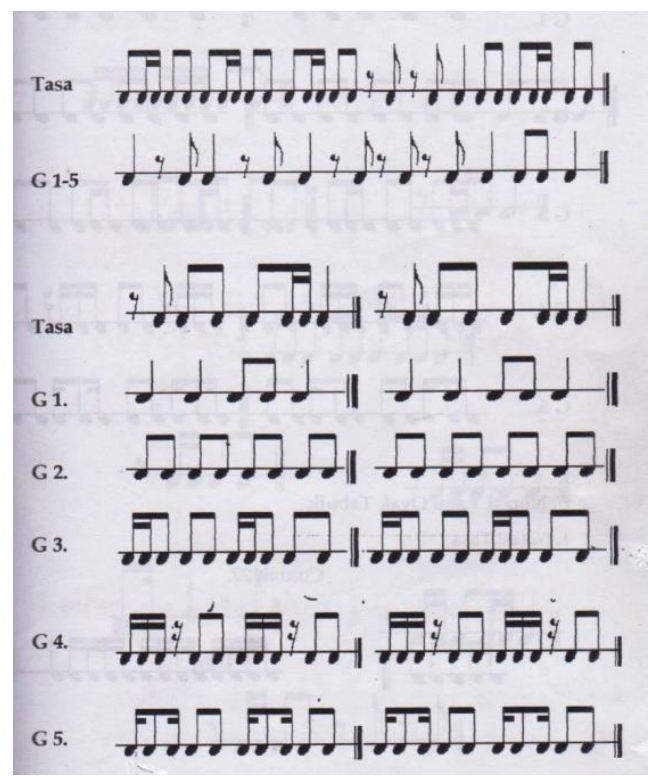

Notasi: gendang dan tasa padapangka matam dan matamlagu Kureta Mandaki
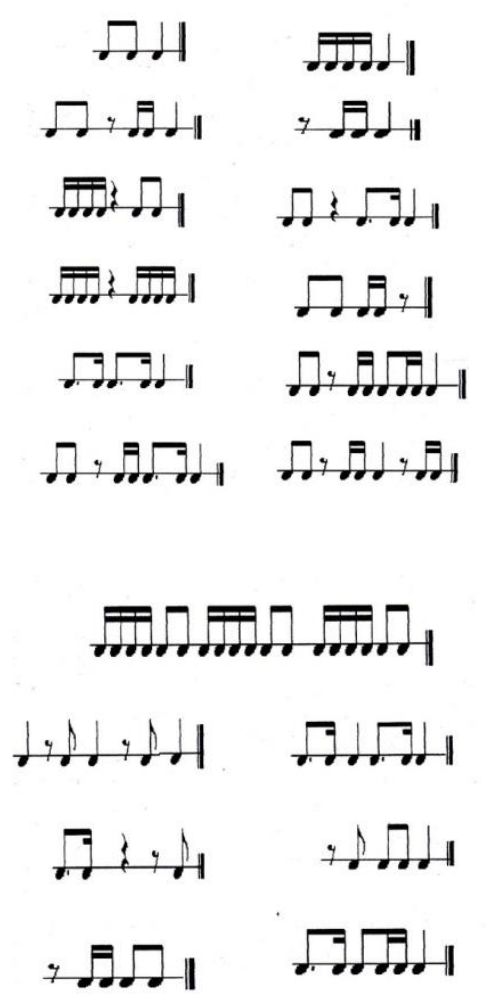

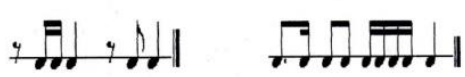

Notasi: motif dan pola ritme tasa pada bagian matam lagu Kureta Mandaki. 


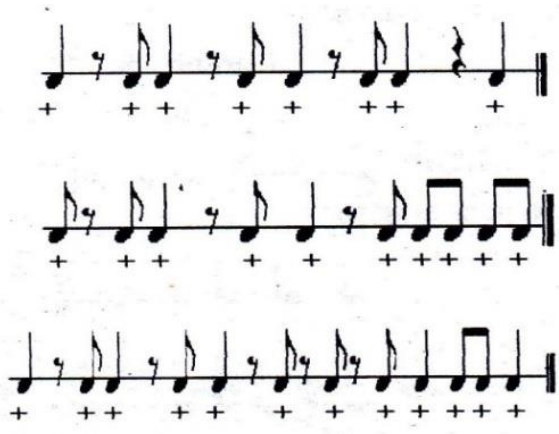

Notasi: pola ritme ikua matam Kureta Mandaki; pola ritme ini sama dengan pola ritme ikua matam Siontong Tabang.

\subsection{Lagu OyakTabuik}

\subsubsection{Metode ceramah}

Melalui metode ceramah dijelaskan bahwa, lagu Oyak Tabuik adalah salah satu lagu gandang tasa yang banyak dimainkan oleh grup-grup gandang tasa di berbagai desa dan kelurahan di Kota Pariaman. Ciri lagu ini adalah tempo cepat, dinamik keras (sejak dimainkan sampai akhir lagu, dinamik tetap keras), enerjik, dan bersemangat. Ciri-ciri ini menjadi karakter dari lagu Oyak Tabuik. Pola ritme yang dimainkan antargendang berbeda-beda, sehingga menghasilkan jalinan antarritme gendang. Jalinan pola ritme pada gendang memiliki tingkat kesulitan dari lagu Siontong Tabang dan Kureta Mandaki. Pola ritme gendang lagu Oyak Tabuik bersifat ostinato (berulang-ulang) yang bisa dimainkan dalam beberapa variasi ritme. Antara pemain gendang yang satu dengan lainnya tidak terlalu terikat ketat memainkan pola ritme bakunya, asalkan tidak terlalu jauh menyimpang dari pola ritme dasarnya, sehingga kesan musikal dan karakter lagu secara umum masih dirasakan sebagai lagu Oyak Tabuik: keras, enerjik, dan cepat (Asril, 2016: 240). Lagu Oyak Tabuiksering dimainkan untuk membangun suasana gembira di luar konteks ritual Tabuik. Misalnya, untuk memeriahkan pesta perkawinan, bahkan dimainkan pula pada prosesi penganten yang dimainkan bersama lagu Matam Panjang.

Lagu Oyak Tabuik merupakan lagu yang sangat terkait dengan pertunjukan dan ritual Tabuik. Lagu Oyak Tabuik dimainkan pada ritus yang berdimensi keras, seperti pertunjukan hoyak tabuik, menebang batang pisang, dan beberapa ritus lainnya. Fungsinya adalah untuk membangkitkan semangat masingmasing kelompok Tabuik. Kecenderungan yang umum dari setiap penyajian lagu ini adalah pada bagian akhir lagu disambungkan dengan lagu Sosohbertempo cepat (Asril, 2016: 237 238). 
Penempatan lagu Oyak Setelah mereka dapat memainkan Tabuikpada bagian terakhir dari materi dengan baik, selanjutnya mereka diberi pelatihan ini disebabkan tingkat kesempatan memainkan tasa. Latihan kesulitannya lebih tinggi daripada lagu- bersama ditekankan pemahaman dan lagu sebelumnya. Tingkat kesulitannya penghayatan pada karakter lagu Oyak terletak pada pola ritme gendang dan Tabuik yang enerjik, keras, cepat, dan tasa. Hasil jalinan ritme ini bersemangat.

memunculkan suatu fenomena berupa Berikut ini beberapa contoh sulitnya menentukan aksentuasi ritme, catatan musik lagu Oyak Tabuik dalam khususnya untuk mengenal tanda-tanda bentuk notasi dari pangka matam di mana penempatan ritme tasa, di atas hingga lagu Sosoh.

permainan jalinan ritme gendang.

\subsubsection{Metode peragaan}

Metode peragaan yang dilakukan pada lagu Oyak Tabuik menggunakan

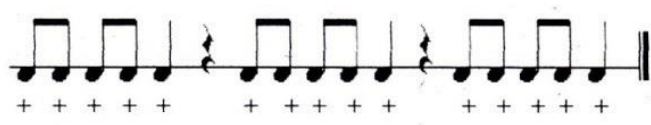

Notasi: pangka matam Oyak Tabuik pola yang sama dilakukan pada lagulagu sebelumnya. Penulis tetap meragakan motif dan pola ritme gendang dan tasa kepada para anakanak agar mereka dapat mengetahui dan meahami. Peragaan dilakukan secara bertahap dan berulang-ulang. Kemudian dilanjutkan latihan bersama.

\subsubsection{Metode latihan bersama}

Latihan bersama dilakukan

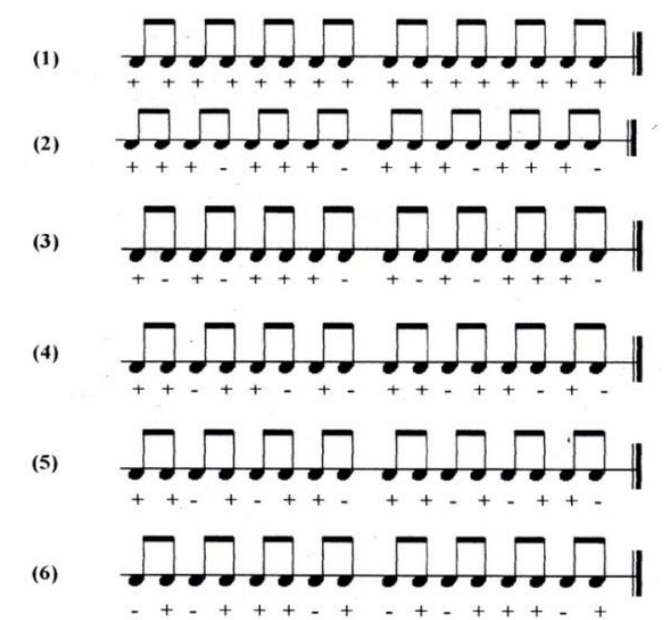
sebagaimana cara yang dilakukan pada lagu Siontong Tabang dan Kureta Notasi: pola ritme gendang matam Oyak Tabuik

Mandaki. Penguasaan memainkan gendang tetap menjadi keharusan yang dilakukan oleh anak-anak, sejak dari pangka matam, matam dan ikua matam. 

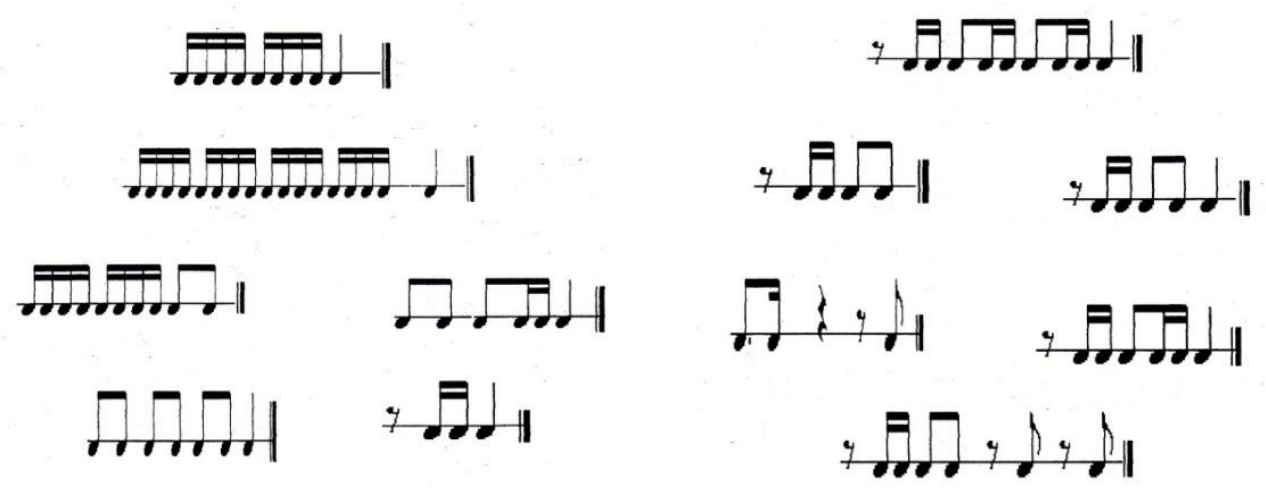

Contoh notasi motif ritme tasa pada matam lagu Oyak Tabuik

Bagian akhir lagu Oyak Tabuik Contoh lagu Sosoh (sumber: Asril, selalu digabungkan dengan lagu Sosoh, 2016: 265)

sehingga lagu Sosoh seolah-olah bagian

kedua dari lagu Oyak Tabuik.
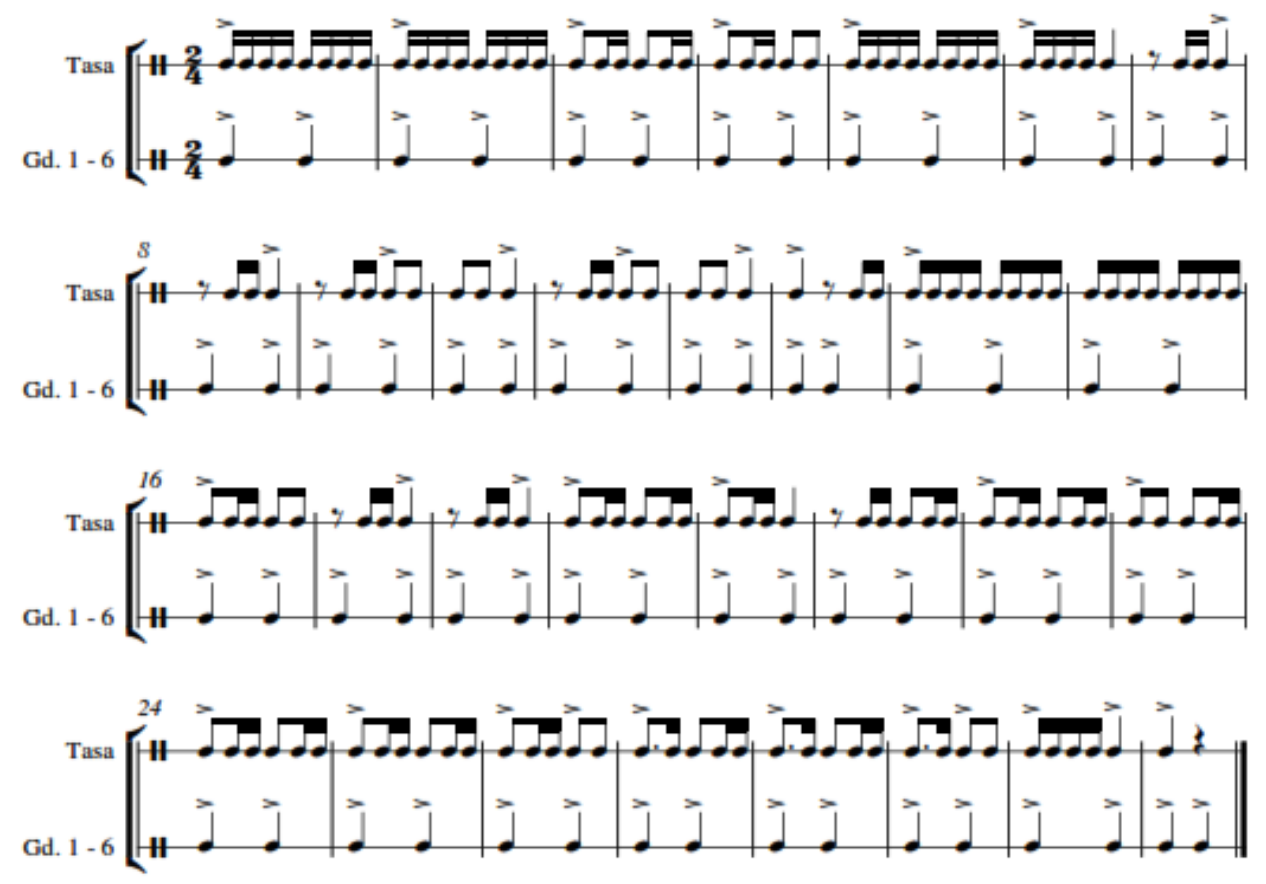
Setelah seluruh materi dilatihkan, dilakukan evaluasi setiap lagu dan secara menyeluruh terhadap materi yang telah dilatihkan. Ada beberapa bagian yang belum tercapai secara maksimal, misalnya pendalaman dan penghayatan terhadap karakter masingmasing lagu. Ini bisa dimaklumi, mengingat karakter anak-anak yang cenderung gembira, ketika menghayati lagu di luar kebiasaan dan sifat anakanak, mereka memerlukan waktu untuk bisa memahami. Akan tetapi, dari segi penguasaan materi, hasil pelatihan ketiga lagu di atas dapat dikuasai dengan baik oleh semua anggota grup gandang tasa anak-anak Sungai Pasak. Modal dan pengalaman mereka menjadi pemain gandang tasa sangat membantu sekali menyerap semua materi yang diberikan. Mereka sangat antusias mengikuti pelatihan, sehingga lagu-lagu yang dilatihkan tampak tidak begitu sulit bagi mereka.

\section{KESIMPULAN}

Grup gandang tasa anak-anak Desa Sungai Pasak pernah mencapai prestasi puncak sebagai juara festival gandang tasa antargrup anak-anak sekota Pariaman. Mereka juga pernah melakukan pertunjukan ke kota-kota besar, seperti Padang dan Jakarta, mengalami degradasi prestasi setelah munculnya grup-grup gandang tasa baru dari kelompok anak yang mampu menggeser posisi mereka. Degradasi prestasi berdampak pada semangat mereka bermain gandang tasa. Sebagai anak-anak, mereka belum mampu menerima kenyataan yang dihadapi. Akan tetapi, melalui pelatihan gandang tasa dengan materi lagu-lagu yang tidak biasa mereka mainkan, seperti Siontong Tabang, Kureta Mandaki, dan Oyak Tabuik, mampu membangkitkan kembali gairah mereka bermain gandang tasa. Ketiga lagu itu telah membuka semangat dan cakrawala mereka dari stagnasi atas lagu-lagu yang mereka miliki.

\section{KEPUSTAKAAN}

Asril. (2016). "Tabuik: Pertunjukan Budaya Hibrid Masyarakat Kota Pariaman, Sumatra Barat." Disertasi, Program Pascasarjana, Institut Seni Indonesia Yogyakarta.

. (2015). "Peran Gandang Tasa dalam Membangun Spirit dan Suasana pada Pertunjukan Tabuik di Pariaman".Dalam Humaniora: Jurnal Budaya, Sastra, dan Bahasa, Vol 27 
No.1 Februari, hal. 67-80.

(2008). "Musik Tradisi
sebagai Penciptaan Karya
Baru". Makalah, disajikan
pada Pelatihan \& Workshop
Manajemen Produksi Musik
di Dinas Parsenibud
Kabupaten Tanah Datar,
Batusangkar 20-21 Oktober.
(2003). "Musik Nusantara:
Gandang Tambua". Buku
ajar (tidak dipublikasikan),
Padangpanjang: Sekolah
Tinggi Seni Indonesia.

Bahar, Mahdi., et al. (2010). "Pemanfaatan Khazanah Tradisi Musik Gandang Tambua Minangkabau dalam Rekayasa Penciptaan Genre Baru Ansambel dan Musik Lapangan (Penciptaan Prototipe Ansambel dan Lagu-lagu Musik Gong Tambur sebagai Model Pengembangan)". Laporan penelitian. Padangpanjang: STSI Padangpanjang.

Muchtar, Asril. (2005), "Gandang Tambua: Musik Pembangkit Semangat 'Heroik' dan
'Patriotik', dalam Upacara Tabuik di Pariaman, Sumatra Barat". Dalam Jurnal Panggung STSI Bandung, No. XXXVII, hal. 67-74.

Muchtar,

Asril. (2002). "Pemberdayaan Musik Tradisi Minangkabau dalam Era Kembali Bernagari”, Makalah disajikan di Batu Sangkar, 7 Oktober.

Pasaribu, Ben M. (1992). "Taganing Batak Toba: Suatu Analisis Struktural dan Stratifikasi Sosial", dalam Sugeng Nugraha (ed.). Seni Pertunjukan Indonesia. Surakarta: Masyarakat Seni Pertunjukan Indonesia.

Purba, Mauly. (1991). "Mangindo Gondang di dalam Penyajian Musik Gondang Sabangunan pada Masyarakat Batak Toba". Jurnal Masyarakat Musikologi Indonesia, Tahun II No. 2, hlm. 134-163. 
FILOSOFI "BATOBOH": Dalam masyarakat Minangkabau upacara-upacara yang dilakukan sebelum mendirikan bangunan baik Rumah Gadang maupun Balairung (Balai Adat) serta bangunan lainnya yang dikenal dengan beberapa upacara yang disebut dengan batoboh. Batoboh berasal dari kata Taboh yang artinya menebang atau mengambil sesuatu, jadi dengan mengambil kayu dihutan sebagai bahan utama dalam membangun rumah dan bangunan lainnya. Upacara Batoboh ini sangat bermanfaat bagi masyarakat Minangkabau yaitu dapat meningkatkan Gotong-Royong dan solidaritas antar sesama suku Minangkabau karena memberi kesempatan kepada kerabat-kerabat untuk terlibat dalam pembangunan rumah serta bangunan lain.

Alamat Redaksi: LPPMPP ISI Padangpanjang Jalan Bahder Johan Padangpanjang 27128 Sumatera Barat Telp. (0752) 485466, Fax.(0752) 82803 e-mail: batoboh@gmail.com

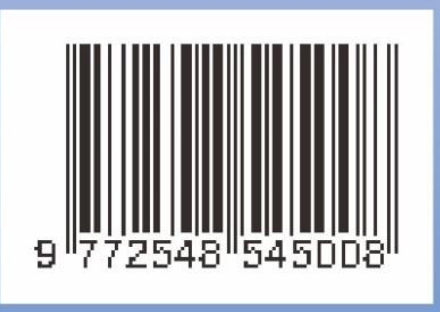

